\title{
HOSPITAL GOVERNANCE, HYGIENE AND CLEANING: NURSE MANAGEMENT SPACE ${ }^{1}$
}

\author{
Lucieli Dias Pedreschi Chaves², Sílvia Helena Henriques Camelo³, Marcela Rezende Silva ${ }^{4}$, Nilce Mara Silva \\ Ana Paula Pereira ${ }^{6}$
}

${ }^{1}$ Extracted from the thesis - Governance in hospital hygiene and housekeeping: implications for nursing work, submitted to the Programa de Pós Graduação em Enfermagem Fundamental of the Escola de Enfermagem de Ribeirão Preto (EERP), Universidade de São Paulo (USP), in 2012.

2 Ph.D. in Fundamental Nursing, Professor at the EERP/USP. Ribeirão Preto, São Paulo, Brazil. E-mail: dpchaves@eerp.usp.br

${ }^{3}$ Ph.D. in Fundamental Nursing, Professor at the EERP/USP. Ribeirão Preto, São Paulo, Brazil. E-mail: shcamelo@eerp.usp.br

${ }^{4}$ Undergraduate student of the Curso de Enfermagem of EERP/USP. Ribeirão Preto, São Paulo, Brazil. E-mail: marcela.rezende. silva@usp.br

${ }^{5}$ Master's student at the Programa de Pós Graduação em Enfermagem Fundamental of EERP/USP. Nurse at the Hospital das Clínicas da Faculdade de Medicina de Ribeirão Preto. Ribeirão Preto, São Paulo, Brazil. E-mail: nilcemara.silva@hotmail.com

${ }^{6}$ M.Sc. Sciences. Nurse at the Centro de Referência da Saúde da Mulher, Hospital das Clínicas, Faculdade de Medicina de Ribeirão Preto. Ribeirão Preto, São Paulo, Brazil. E-mail: appereira@hcrp.usp.br

\begin{abstract}
Governance in hygiene and cleaning has shown to be a trend nowadays in hospital organizations. This is a reflective study that aimed at discussing and theoretically thinking over the implementation of governance services in hospital hygiene and cleaning, identifying possibilities, limitations and challenges posed to the current managerial work of nurses. The services implementation has huge potentials like quick cleaning of units, scaling the replacement of staff in public institutions by outsourcing workers, and appropriateness of the design which are aspects that impact on the safety of users. Limitations concern the human resources capacitybuilding and proper work in the hospital setting. This service makes room for the managerial work of nurses that are faced with the challenge of adapting the managerial tools used to forecast and provide human and material resources, planning, decision making, supervision and continued education on the specificity of the hospital hygiene and cleaning service.
\end{abstract}

DESCRIPTORS: Organization and administration. Hospitals. Nurses.

\section{GOVERNANÇA, HIGIENE E LIMPEZA HOSPITALAR: ESPAÇO DE GESTÃO DO ENFERMEIRO}

\begin{abstract}
RESUMO: Governança em higiene e limpeza tem se mostrado uma tendência, na atualidade, nas organizações hospitalares. Tratase de estudo reflexivo que teve como objetivo discutir e refletir teoricamente acerca do serviço de governança em higiene e limpeza hospitalar, identificando possibilidades, limitações e desafios da atuação gerencial do enfermeiro. A implantação desse serviço apresenta potencialidades como agilidade na realização da limpeza de unidade, dimensionamento da reposição do quadro de pessoal em instituições públicas com a terceirização de trabalhadores, além de adequação do dimensionamento, aspectos que repercutem na segurança do usuário. As limitações dizem respeito à capacitação de recursos humanos e adequação de atuação no cenário hospitalar. Este serviço representa espaço de atuação gerencial do enfermeiro que tem o desafio de adequar os instrumentos gerenciais utilizados para previsão e provisão de recursos humanos e materiais, planejamento, tomada de decisão, supervisão e educação permanente à especificidade do serviço de higiene e limpeza hospitalar.
\end{abstract}

DESCRITORES: Organização e Administração. Hospitais. Enfermeiros. Enfermeiras.

\section{GOBERNANZA, HIGIENE Y LIMPIEZA HOSPITALARIA: ESPACIO DE GESTIÓN DEL ENFERMERO}

RESUMEN: La gobernanza de la higiene y limpieza en las organizaciones hospitalarias es una tendencia actual. Se trata de un estudio reflexivo que objetivó discutir y reflexionar teóricamente acerca del servicio de gobernanza de la higiene y limpieza hospitalaria, identificando las posibilidades, limitaciones y desafíos del desempeño gerencial del enfermero. La implantación de este servicio tiene potencialidades como la agilidad en la realización de la limpieza de la unidad, el dimensionamiento de la sustitución del personal de las instituciones públicas por trabajadores tercerizados, y la adecuación del dimensionamiento, aspectos que impactan la seguridad del usuario. Las limitaciones se refieren a la formación de recursos humanos y adecuación de actuación para el ámbito hospitalario. Este servicio representa un espacio de actuación gerencial del enfermero que tiene el desafío de adaptar los instrumentos de gestión utilizados para previsión y provisión de recursos humanos y materiales, planificación, toma de decisiones, supervisión y educación continua a la especificidad del servicio de higiene y limpieza hospitalaria.

DESCRIPTORES: Organización y administración. Hospitales. Enfermeros. Enfermeras. 


\section{INTRODUCTION}

Hospital organization is one of the most complex health institutions, due to the co-existence of countless care and administrative procedures, several simultaneous lines of production, and fragmentation of decisions on care, additionally to the presence of a multi-professional team with a high degree of autonomy. Hence, it makes intensive and extensive use of technology and can also serve as a teaching and learning space, additionally to a field of scientific production. ${ }^{1}$

The practices developed in hospital institutions in the current century gradually incorporate care indicators about health recovery as a way to assess the quality of services. Today there are quick advances in care modernization, incorporation of technologies and knowledge, as well as in the appraisal of patients which are now called client/ user. $^{2}$

When meeting the demands of social actors as clients/users, funders and health plans, hospitals have incorporated to their activities some procedures and processes that make a difference in relation to the competitors and improve the quality standard of services provided. ${ }^{2-4}$

In face of the unpredictability and competitiveness in the current context of hospital organizations, effective and efficient management is an important differential to be achieved. In this sense, management based on hospital governance emerges as a feasible alternative to hospitals seeking for the best quality standards in management and services delivery through rationality and administrative efficiency. The implementation of hospital governance is a new perspective of services management to hospital, of services and action reorganization pursuing rationality and proper use of resources in technical and managerial aspects.

Hospital governance services focus directly on the comfort, safety and well-being of internal and external client/user, in an attempt to change the environment to make it cozier. The implementation of this kind of service makes quality and efficiency key elements in health production.

The topic of governance in hospital hygiene and cleaning is closely linked to other areas in this setting, notably regarding nursing that accounts for expressive professional contingent of the hos- pital. Governance has direct impacts on the work of nurses both in managerial and care actions. In operational terms, nursing has been in charge of the hospital unit cleaning, and now faces a new reality ranging from resources planning for carrying out procedures to the technical development of the unit cleaning. This situation brings about questions on how to properly design the specific actions of nursing professionals, which actions could be assigned to other professionals with no damage to the nursing work space, but redefining/consolidating the specificity of the nursing scope of action.

The interface between governance in hygiene and cleaning and the nursing work justifies the discussion about the implications of implementing this kind of service on the nurse managerial work. Above all, it is worth mentioning the aspects regarding the activities of nurses who, in the Brazilian context, in addition to care, managerial and educational activities related to health care, have been invited to manage other services in hospitals, like hospital hygiene and cleaning services that stand for a new room of managerial work to this professional.

In this article, governance in hospital hygiene and cleaning is approached in its correlation with the nursing work organization, a situation that arouse interest for being a contemporaneous matter.

Hence, the aim of this study was to discuss and theoretically think over the implementation of the governance service in hospital hygiene and cleaning identifying possibilities, limitations and challenges posed to nurse managerial work in this service.

\section{METHOD}

A reflexive study was performed based on the in-depth discursive formulation on a specific topic, defining analogies, presenting different theoretical and/or practical viewpoints. ${ }^{5}$

This way, the conceptual aspects of hospital governance were approached, disclosing the context of hospital hygiene and cleaning services, advancing to reflections about the potentials and limitations to the implementation of these services, concluding with some challenges posed to the managerial work of nurses in this new room. 


\section{Hospital governance}

Innovations in the field of organizational management refer to applied concepts that qualify the administration methods and bring about reflections about the limits of scope or nomenclature. An example regards hospital governance as a management model. The term has been employed today like as if its meaning was clear and understood by the public at large and by professionals in the field of management and health; however, the actual understanding of its meaning is arguable.

The word "governance" used in studies related to the administrative areas of organizations has a meaning focused on the act of governing. ${ }^{6}$

In hospital, governance gathers the basic hospital managerial services, namely: assets, nutrition and food security; laundry; hygiene and cleaning service. The management of all these services should be focused on the client/user and on the quality of services to qualify the care provided. ${ }^{7}$

Additionally to the care, comfort and wellbeing in inpatient care units, sanitation must be ensured as a means to prevent hospital infection. These duties are typical to the service of governance in hygiene and cleaning. ${ }^{6}$

The few existing studies about this topic in the hospital area characterize governance as the service that takes on the responsibility for the comfort and well-being of guests, being characterized by the following services: laundry, hygiene and cleaning. ${ }^{6}$ Governance service is based on actions that demand personnel training to be consistently updated regarding processes and compliance with the laws in force. ${ }^{8}$

Hence, hospital institutions face the administrative challenge of incorporating this new managerial model; however, the implementation of specialized services is indelibly correlated to the objective of reducing financial costs and adjustment to the environment specificity without changing the hospital scenario. It is worth mentioning that costs cannot impair the service delivery as the quality of procedures depends on the proper development of the organization management, technical and continued planning, and responsible execution.

The hospital hygiene and cleaning service is part of the logistic support of specialized services, contributing to promote the control of environment-related hospital infection, enabling the preservation of physical assets of the institution, and promoting well-being to internal and external clients, staff members and visitors in the hospital environment. ${ }^{2}$

The difficulty in adjusting the governance service lays on the difficulty in finding professionals capable of managing this service in a skilled and efficient way, prioritizing humanization and quality of health services. One of the main differentials of this service in a hospital institution in comparison to a hotel is on the strict rules and technical criteria that must be observed by governance so that cleaning and hygiene services are properly delivered, using specific products to prevent contaminations and infections. ${ }^{6}$

Considering the health work characteristics, the use of these services should be adjusted to the context and specificity of the hospital setting, the contingent of professionals involved and, mainly, to the uniqueness of the client/user needs that are different from the consumer or client of other services.

In this light, hospitals recognize the need for changing and providing a cozy and humanized environment, ${ }^{9}$ rather than cold and impersonal. Recently, institutions have incorporated the hospital governance service into their flowchart, including the service of hospital hygiene and cleaning in a continuous search for excellence, matching the hospital objectives to the act of hosting.

\section{Framing the hospital hygiene and cleaning service}

The hospital hygiene and cleaning service can be performed by the hospital staff or outsourced. When performed by the hospital staff there is the benefit of personal services, following the institution objectives; however, outsourcing services could bear advantageous results regarding costs control. ${ }^{2}$ It is worth mentioning that the decision about own or outsourced services depends on the legal and organizational situation of each institution, and both modalities bring advantages and disadvantages.

Moreover, hospital hygiene and cleaning services have criteria regarding the staff dimensioning such as: qualification of the team available; working hours; classification of hospital areas in the light of criticality, blueprint and time of construction; region where the hospital is located 
(rural or urban area); internal working conditions; degree of demand from internal and external clients; administrative policies, among others. ${ }^{2}$

A way of dimensioning the staff that is sometimes used by organizations is based on the footage of the physical area of construction. One must consider several factors that interfere in the practice and performance of cleaning workers. According to the Brazilian standard, a cleaning worker performs cleaning activities on $400 \mathrm{~m}^{2}$ every 8 -hour shift in free areas, and $300 \mathrm{~m}^{2}$ every 8 -hour shift in closed areas. ${ }^{10}$

Today, the hospital hygiene and cleaning service also faces difficulties that could be translated by the current challenges of incorporating the governance concept. This paradigm break, or change of behavior, cannot interfere in the work practice and the final purpose of the service.

The inclusion of governance services in hospital hygiene and cleaning comprises making minimum investments in financial and materials. This incorporation should be based on the planning and goals defined prior to the service implementation. ${ }^{6}$

The implementation of the governance service in hospital hygiene and cleaning demands a serious study on the organizational, environmental characteristics and the hospital demand such as: areas to be sanitized and their footage; cleaning technique according to the criticality of the areas and services; periodicity of action established in the activities schedule; responsibilities and rights involved, with description of the rules and laws; criteria of monitoring and evaluation; acceptable time term to remedy unconformities and disciplinary sanctions and related progression. ${ }^{8}$

The smart and efficient adaptation of this department to the hospital characteristics is a huge challenge that mainly involves understanding the differentiated profile of health users and the specificities of the hospital environment. In other words, the governance model should be adjusted to the hospital setting, thinking over its contributions to implement the governance service in hospital management.

The implementation of a governance sector in hospitals is a way of managing the supporting services directly in charge of safeguarding the cleaning of the unit, rooms, wards and common areas.
In the past, the hygiene and cleaning services in the Brazilian hospitals were exclusively operational. Regardless if own or outsourced, there are models where the area of hospital hygiene is directly bound to the nursing area, whereas in other models it is bound to the administrative board. Many times in these models management is just operational, with no correlation to the interface areas, missing a political status that allows for a systemic view of the impacts resulting from its processes on the remainder hospital, as well as the active participation in the decision-making process influencing aspects related to the selection of furniture, coatings, chemicals, equipment and hospital bed management. ${ }^{7}$

Within the hospital governance service, managers should be capable of aligning processes, planning activities with the hospital managers like the nursing management. The nurse is in charge of ensuring the required conditions to meet the demands emerging from such interventions, i.e., forecast/provision of human and material resources, capacity-building and supervision to clean the unit.

It is worth highlighting that, although nurses are the professionals making interface with this service, the nursing team is not necessarily operationally responsible for the unit cleaning, since Law 7498/86 which provides for the professional exercise of nursing does not provide for the organization of the hospital hygiene and cleaning service. Nonetheless, Article 11 states that nurses perform all nursing activities and, as a member of the health team, are in charge of the prevention and systematic control of hospital infection and transmissible diseases in general, and prevention and systematic control of potential damages to clients during nursing care. ${ }^{11}$

The unit cleaning is renowned for being one of the ways to keep a safe hospital environment and used to be performed by the nursing team. Today, in some institutions it is performed by workers specifically hired for that purpose through the coordination of a hospital governance service. It is worth mentioning that the user unit has been defined as the set of spaces and furniture assigned to each user, with components varying from hospital to hospital. ${ }^{12}$

The unit cleaning is classified in concurrent and terminal cleaning. Concurrent cleaning is performed everyday on some parts of the user 
unit like toilets and furniture, during the period of stay. Terminal cleaning is performed on all the unit components, including walls, and is indicated when the hospital bed becomes vacant due to discharge, death, transfer, extended hospitalization, outbreaks and end of isolation. ${ }^{12}$

Both kinds of cleaning are performed with the main purpose of preventing the dissemination of microorganisms that colonize the surfaces. To break the epidemiological chain of infections, there are rules on the use of proper products to the hospital sanitation. Therefore, due to the particularities of units' cleaning in hospital setting, which bears different and unique traits, there is the need for specific training to the hygiene and cleaning service personnel.

The hygiene and cleaning team, composed by cleaning assistants and maids, should be skilled, training through proper procedures/ protocols and prepared to work with persons, as they have direct contact with users, influencing on their satisfaction with the services received. Users/ clients believe that cleaning is a visible factor of the quality of services. Additionally to the care, comfort and well-being, inpatient care units must ensure sanitation as a measure to prevent hospital infection. Usually maids are in charge for the concurrent cleaning of inpatient care units, while cleaning assistants are in charge of the terminal cleaning. ${ }^{6}$

Successful hospital governance demands cooperation by the nursing team composed of professionals that provide full-time direct care to clients/users, listening to their needs and seeking for solutions. In other words, the characteristics of the nursing work places it in a differentiated position regarding information that could maximize the hospital governance operationalization. The relationship between the hospital administration and the nursing team could affect the existing cleaning routine and result in more responsible and problem-solving working methods.

As the governance team is in charge of releasing a clean room for a new hospitalization, they must keep harmonious relationships with the reception and maintenance departments to promote agility and efficiency in the care delivered to users. A harmonious relationship between the maid and the nursing teams is crucial as they are both responsible for providing care to patients in the inpatient care unit. ${ }^{12}$
It is important to restate that the interface between the hygiene and cleaning services and nursing services is directly related to the control of infection which is a critical factor to the successful delivery of hospital services.

\section{Potentials and limitations of the implementation of the governance service in hospital hygiene and cleaning}

In view of the reality regarding the implementation of governance services in hospital hygiene and cleaning, it is worth explaining that in the hotel sector this service bears different characteristics from the service provided in hospital settings. In hotels, areas are classified by the kind of accommodations or social areas, while in hospital differentiation is made by the kind of criticality of wards or common circulation areas. The work team must be adapted to enable the professional to incorporate technical knowledge to control hospital infection.

The emergence of diseases in the care environment can be related to the use of incorrect techniques to clean and disinfect surfaces, the undue handling of residues, exposure to occupational risk since, even using personal protection equipment (PPE), if there are unconformities that which could control starts disseminating infections, providing risk rather than safety. Such inadequacies regarding hygiene and cleaning services may entail sanctions to the health institution resulting from incompliance with sanitation laws.

The nursing team can foster discussion with the decision-making administrative levels of the health institution regarding the requirement of problem-solving actions to improve the hospital cleaning performance, through official reports issued by the health institutions and the interdisciplinary work with the service of hospital infection control. In addition to the technical justifications, the demand for comfort, safety and well-being of users or clients and their companions should also be incorporated.

The implementation of hospital governance and hygiene and cleaning services is a current tendency in both public and private services. The challenge posed for this implementation lays on raising awareness among administrators and incorporating values in individuals engaged in the process. The decision-making process regard- 
ing the implementation of governance service in hospital hygiene and cleaning demands strict diagnosis to define needs based on a descriptive study of the areas to be comprised by the service.

If the aforementioned aspects are disregarded there could be potential negative or restrictive implications to the implementation of the governance service in hospital hygiene and cleaning: ${ }^{8}$

- Inadequacies in the process of preparing calls for bid or contracts, not providing the required details about the service to be delivered, damaging the result of services delivery and showing negative quality indicators;

- Lack of formal and standardized instrument to assess the quality of the service performed and the dimensioning of staff, hindering the monitoring of work performed;

- Capacity-building or training that is inadequate or not delivered facilitates deficiencies in the technical practice exposing the professional, team, user or client and companions to the lack of safety and to risks;

- Improper attitudes and relationships in the hospital setting. An ethical and respectful approach is crucial to keep professionalism in the relationships with users, family members, multiprofessional team and nursing team. This situation has important interface with issues related to direct supervision of the work performance, and actions on permanent education of workers in services of governance in hygiene and cleaning;

- Hierarchical conflicts in the lack of definition of supervision and coordination;

- Loss of reliability of the service provided due to doubts of the care team regarding the qualification or technical capacity of the hospital hygiene and cleaning team;

- Difficulty in adjusting the hotel model to the hospital model;

- Breach of contracts or outsourced services, and abolishment of the governance service of hospital hygiene and cleaning.

Changing the duty of unit cleaning upon the implementation of the governance service in hygiene and cleaning changes the nursing routine as it excludes the unit cleaning from the duties assigned to nurses.

It is worth mentioning that in the nursing team the nurse is the professional typically assigned with the duties of supervising or co- ordinating the governance services in hospital hygiene and cleaning. Hence, even if nursing is not responsible for supervising hygiene and cleaning services, in the everyday practice it takes on this role when managing the care sectors. ${ }^{8}$

By centralizing the inpatient care unit cleaning operations under the governance responsibility, the nursing team optimizes its time to attach priority to providing care. ${ }^{13}$ However, the existence of governance services in the user or client unit does not waive the nursing team responsibility, which is also in charge of checking the medical-hospital equipment used by the patient during hospitalization. Governance is in charge of verifying other equipment like minibar, television and lamps, and then request maintenance service to the responsible team. In face of the situation of change, duties should be described. ${ }^{6}$

The quick cleaning of the unit by the nursing team is highly appraised when this activity starts being performed by the housing team in hygiene and cleaning. Unit cleaning quickness is perceived as a factor that facilitates the nursing team work, mainly in face of the high demand for hospitalizations or high turnover rate in some hospital sectors. The quick cleaning of unit can be positively described by the nursing team; however, it does not characterize quality and proper role performed, but just time optimization.

The likely potentials to be considered are as follows: transfer of the cleaning duty from the nursing unit to the governance service in hospital hygiene and cleaning, emphasizing that nursing aides and technicians assigned with the unit cleaning among its professional duties, can spend more time with care; agility in the unit cleaning to release disinfected hospital beds for new hospitalization, thus optimizing the flow, improving management and quality indicators, problem-solving and costs control, staff replacement and control of dimensioning and humanization, comfort and safety.

The work performed by the nursing and cleaning teams demands consistency among activities. The joint work favors the qualification of development of practical and managerial actions in the sector where the governance service in hygiene and cleaning is implemented. The work of the managing nurse is crucial to the working process, avoiding loss of operational and financial capacity to the health institutions. Thus, the 
management performed by nurses in the working unit impacts on the interdisciplinary activities and supporting team.

It is worth mentioning that, among other services, the coordination with activities performed by the service of hospital infection control allows gathering efforts to adopt joint and supplementary measures to qualify the work performed by different teams in the hospital aiming at preventing hospital infection.

\section{Reflecting about managerial instruments of nurses in hospital governance, hygiene and cleaning}

Nurses have been required to manage governance services in hospital hygiene and cleaning and, to that, adjust classic managerial tools to this new context. The academic and managerial experience in these services brings about some considerations. It is worth mentioning that scientific production specifically focused on the hospital care context is very low. Therefore, this article contributes with the summary of some hotel administration concepts in the context of health field, based on the experience of the authors in performing research services and development, and in reinterpreting the use of managerial instruments in the light of governance in hospital hygiene and cleaning.

In this sense, planning is a managerial tool that allows nurses to establish priorities and objectives to change a given situation found to build proper environment during the stay of the client/ user. Considering the complexity of situations and actors involved, it is a tool that allows nurses to build integrated and participatory planning that contributes to the organization of health services and to cope with institutional conflicts and problems. It is a powerful instrument to change reality, as it increases the capacity of guidance, management and control of the social system.

Moreover, still having planning in mind, it has interface with the decision-making process that involves different elements and is of utmost importance due to its characteristics of temporality and adequacy inherent to this area, since the phase of planning and implementing the hygiene and cleaning management until the performance of daily activities, there are several situations demanding detailed and contextualized analyses to support the decision-making process.
Regarding the actions performance, another managerial instrument worthy of notice regards the proper distribution and use of health human resources that have been referred as the major challenges posed to institutions both in quantitative and qualitative aspects, by virtue of the implications of the inadequate dimensioning of the resources on the result of the care provided. The numerical and qualitative inadequacy of human resources may damage the clients' right to health care free of risks, since the hygiene and cleaning aspects are directly related to the transmission of infection, additionally to aspects related to comfort and hospitality.

The human resources dimensioning is part of the initial stages of governance in hygiene and cleaning services planning, by the time of surveying sectors, areas, criticality, periodicity and scope of cleaning operations that have a direct impact on the quantitative and qualitative provision of human resources.

Moreover, it is worth highlighting the need for continuous and coordinated investments in educational actions approaching technical-scientific knowledge, additionally to relational knowledge, coordinated actions at different levels to facilitate the qualification of labor force in hospital hygiene and cleaning services.

Nurses play a core role regarding the qualitative and quantitative definition of the material required to perform the work; establishment or technical specifications; participation in the procurement process, forecasting and provision, organization, control and assessment of the materials. ${ }^{14}$

Supervision, in the light of coordinating actions, should be grounded on the contract terms set forth to develop the hygiene and cleaning services. The supervision-related activities are part of an important managerial axis since most of the activities are performed by the hygiene and cleaning team. It could serve as an important tool to the nurses' managerial practice, facilitating the redesign of services, enabling actions free of damages, risks and grievances to users, improving processes and developing the team of which they part.

It is worth mentioning that, for outsourced corporations, the nurse in service should not be the supervisor of the hygiene and cleaning team to prevent labor links with the contracting 
corporation; however, in practice, many times the nurse in service is the reference to that team in the units.

Another managerial tool concerns the emphasis on the process of implementing the quality management, adopting quality indicators to the sector of hygiene and cleaning, rationalizing the assessment with routines, standardized procedures and increased safety when performing activities, effective participation in planning, and time optimization.

Hence, it is about using the managerial instruments respecting the context of the specificities found in the setting of hospital hygiene and cleaning services that somehow have an important interface with nursing services but that, on the other hand, bear particularities that demand a detailed analysis to adopt the best approach.

Finally, the potential contribution by nurses in the pursuit of a unified governance system to different contexts of clinical, administrative and logistical support systems, notably the management of persons, is noteworthy. ${ }^{15}$

\section{FINAL CONSIDERATIONS}

The perspectives regarding the hospital governance service implementation focus on improving the management process. This tendency was found to be the focus of study for the learning and managerial work of nursing in Brazil.

The interface between the governance service in hygiene and cleaning and the nursing team work demands aligning the activities. The joint work favors the qualification of practical and managerial actions in hospitals where the governance service in hygiene and cleaning is implemented.

The general aspects, potentials and limitations, as well as the managerial instruments presented herein minimize errors in the service implementation in face of the relevance of its implications to the nursing work, users and hospital administration. Thus, the adoption of continuous monitoring strategies is recommended, designing indicators and performing quality surveys. Nonetheless, the hygiene and cleaning sector faces serious problems regarding the implementation of a philosophy of quality, mainly in team-related factors like shortage of professionals, lack of knowledge about the approach, lack of commitment, and resistance to changes.

There is no doubt about the nurses' managerial capacity in face of this new challenge considering their academic background allied to the professional exercise with private management practices, and the interface with the governance service in hygiene and cleaning services. These factors lead us to reflect about nurses as the most adequate professionals to take on the responsibility for these services.

Therefore, new work fields are being proposed and the governance service in hospital hygiene and cleaning emerges as an innovative strategy to manage care and services, as well as a challenge to professional nurses.

\section{REFERENCES}

1. Osmo AA. Processo gerencial. In: Gonzalo VN, Malik AM, editores. Gestão em Saúde. Rio de Janeiro (RJ): Guanabara Koogan; 2012. p.127-37.

2. Vecina Neto G, Malik AM. Gestão em saúde. Rio de Janeiro (RJ): Guanabara Koogan; 2011.

3. Pertence PP, Melleiro MM. Implantação de ferramenta de gestão de qualidade em hospital universitário. Rev Esc Enferm USP. 2010; 44(4):1024-31.

4. Joint Commission. About the Joint Commission. 2011 [acesso 2014 set 09]. Disponível em: http:// www.jointcommission.org/about_us/about_the_ joint_commission_main.aspx

5. Matheus MCC, Fustinoni SM. Pesquisa qualitativa em Enfermagem. São Paulo (SP): Livraria Médica Paulista Editora; 2006.

6. Taraboulsi FA. Administração de hotelaria hospitalar. $3^{\text {a }}$ ed. São Paulo (SP): Atlas S.A.; 2006.

7. Boeger M. A interface da hotelaria hospitalar e o controle de infecção hospitalar. J Infect Control. 2013; 2(2):124-5.

8. Pereira AP. Governança em higiene e limpeza hospitalar: implicações para o trabalho de enfermagem [dissertação]. Ribeirão Preto (SP): Universidade de São Paulo. Escola de Enfermagem de Ribeirão Preto; 2012.

9. Morgan A. Hotelaria hospitalar - qualidade nos serviços, satisfação garantida [acesso 2014 ago 4]. Disponível em: http:/ / www.cpt.com.br

10. Mezzomo AA. A importância da qualidade dos serviços de higiene e limpeza. Hosp. Adm. Saúde. 1993;17(1):5-7

11. Brasil. Lei n. 7.498, de 25 de junho de 1986: dispõe sobre a regulamentação do exercício da Enfermagem e dá outras providências. Diário Oficial da União. 26 Jun 1986. 
12. Souza GG. Hotelaria hospitalar: conceitos da hotelaria adaptados ao setor hospitalar [monografia]. Belo Horizonte (MG): Universidade Federal de Minas Gerais; 2006.

13. Boeger MA. Gestão em hotelaria hospitalar. $2^{\mathrm{a}}$ ed. São Paulo (SP): Atlas S.A.; 2005.

14. Castilho V, Gonçalves VLM. Gerenciamento de recursos materiais. In: Kurcgant P, coordenador.
Gerenciamento em enfermagem. Rio de Janeiro (RJ): Guanabara Koogan; 2010. p.155-67.

15. Lorenzetti J, Lanzoni GMM, Assuiti LFC, Pires DEP, Ramos FRS. Gestão em saúde no Brasil: diálogo com gestores públicos e privados. Texto Contexto Enferm [online]. 2014 [acesso 2014 ago 4]; 23(2)41725. Disponível em: http:/ / www.scielo.br/pdf/tce/ v23n2/pt_0104-0707-tce-23-02-00417.pdf 